\title{
PENGARUH JENIS PELARUT TERHADAP AKTIVITAS ANTIOKSIDAN EKSTRAK ECENG PADI (Monochoria vaginalis Burm F. C. Presel.)
}

The Effect of Different Solvents on The Antioxidant Activity of Rice Hyacinth Extract

(Monochoria vaginalis Burm F. C. Presl.)

\author{
Ida Ayu Gede Padmawati' ${ }^{1)}$, I Ketut Suter ${ }^{2)}$, Ni Made Indri Hapsari Arihantana ${ }^{2)}$ \\ ${ }^{1}$ Mahasiswa Program Studi Ilmu dan Teknologi Pangan, Fakultas Teknologi Pertanian, Unud \\ ${ }^{2}$ Dosen Program Studi Ilmu dan Teknologi Pangan, Fakultas Teknologi Pertanian, Unud \\ Kampus Bukit Jimbaran, Badung-Bali
}

\begin{abstract}
This study was conducted to determine the effect of different solvents on the antioxidant activity of rice hyacinth extract and to find out the right type of solvent used to extract rice hyacinth with the highest antioxidant activity. The experimental design used in this study was a completely randomized design with various types of solvents as a treatment using maceration method. The treatment consisting of four type of solvents i.e water, ethanol, methanol, and acetone. All treatments were repeated four times to obtained 16 experimental units. The data obtained were analyzed by variance and if the treatment had significant effect then followed by Duncan test. The results showed that the various types of solvent treatments had a very significant effect $(\mathrm{P}<0.01)$ on antioxidant activity. The results showed that ethanol solvent had the best treatment which produced an antioxidant activity based on $\mathrm{IC}_{50} \mathrm{of} 0,49 \mathrm{mg} / \mathrm{mL}$, yield of $26.17 \%$, total phenol content of $11.12 \mathrm{mg} \mathrm{GAE} / \mathrm{g}$, total flavonoid content of $8.26 \mathrm{mg} \mathrm{QE} / \mathrm{g}$, total tannin content of 5.18 $\mathrm{mg}$ TAE/g.
\end{abstract}

Keywords: rice hyacinth, maceration, anioxidant activity

\section{PENDAHULUAN}

Eceng padi dikenal sebagai gulma pada tanaman padi namun dapat dimanfaatkan sebagai sayuran untuk dikonsumsi. Tumbuhan ini dikenal dengan nama biah-biah atau bebiah oleh masyarakat Bali. Desa Tajen, Kecamatan Penebel, Kabupaten Tabanan, Bali merupakan salah satu desa yang memanfaatkan eceng padi sebagai bahan pangan untuk dikonsumsi. Umumnya diolah dengan cara ditumis atau direbus.

Wijaya (2018) melaporkan bahwa eceng padi disebut dengan nama eceng lembut yang termasuk ke dalam kelompok gulma air. Gulma air yaitu gulma yang sebagian atau seluruh hidupnya berada di air seperti eceng gondok (Eichornia crasipes) dan genjer (Limnocharis flava L.). Menurut Latha dan Latha (2013), eceng padi termasuk ke dalam famili Pontederiaceae yang dikenal memiliki beberapa sifat sebagai obat dan dapat dikonsumsi sebagai sayur. Penelitian mengenai eceng padi di Indonesia yang pernah dilakukan sebelumnya sebatas habitatnya sebagai gulma pada tanaman padi. Eceng padi dapat berperan sebagai agen fitoremediasi terhadap limbah krom (Putri et al., 2014). Chandran et al. (2011), melaporkan bahwa tanaman eceng padi yang berasal dari areal persawahan di Kaduthuruthy, Kottayam, India, mengandung senyawa-senyawa kimia seperti karbohidrat, protein, asam amino, alkaloid, saponin, senyawa fenolik, tanin, flavonoid, glikosida, fitosteroid, minyak, dan lemak. Latha dan Latha (2013) melaporkan bahwa dengan menggunakan tikus wistar jantan, tanaman eceng padi dapat digunakaan untuk melawan gangguan pada hati dan kerusakan oksidatif. Berdasarkan penelitian tersebut, tumbuhan ini berpotensi sebagai sumber antioksidan alami dan sebagai pangan fungsional. 
Senyawa kimia dalam eceng padi dapat diambil dengan melakukan proses ekstraksi. Metode ekstraksi dengan maserasi digunakan untuk mengekstrak sampel yang relatif tidak tahan panas. Maserasi dilakukan dengan merendam sampel dalam suatu pelarut dalam jangka waktu tertentu. Hal tersebut dilakukan untuk memberikan kesempatan bagi pelarut untuk mengekstrak senyawa bioaktif dalam bahan. Waktu maserasi yang terlalu singkat menyebabkan senyawa yang diekstrak tidak maksimal dan apabila terlalu lama maka senyawa yang diekstrak akan rusak (Utami, 2009). Kelebihan metode ini diantaranya adalah tidak memerlukan peralatan yang rumit, relatif murah, dapat menghindari penguapan komponen senyawa karena tidak menggunakan panas, sedangkan kelemahannya adalah memerlukan waktu yang lama dan pelarut yang banyak sehingga tidak efisien (Meloan, 1999).

Ekstraksi antioksidan dari eceng padi dilakukan dalam jenis pelarut yang berbeda. Hal tersebut dilakukan berdasarkan pertimbangan bahwa persentase ekstraksi dipengaruhi oleh jenis pelarut dengan berbagai kepolaran dan komposisi kimia serta sifat fisik dari sampel. Pelarut yang sering digunakan untuk ekstraksi adalah air, aseton, etanol, dan metanol (Xu dan Chang, 2007). Menurut Novita et al. (2016), pelarut air menghasilkan nilai total fenol yang lebih tinggi dibandingkan dengan pelarut metanol pada ekstraksi beberapa jenis bayam dan sayuran lainnya. Pelarut etanol mampu menghasilkan aktivitas antioksidan tertinggi pada ekstrak daun alpukat (Kemit, et al., 2016). Widyawati et al., 2014 melaporkan bahwa ekstrak metanol daun beluntas mampu menghasilkan total fenol dan flavonoid tertinggi dibandingkan dengan menggunakan pelarut air dan etanol. Pemilihan pelarut disesuaikan dengan kepolaran senyawa yang akan diekstrak yaitu fenol, flavonoid, dan tanin. Senyawa bioaktif tersebut cenderung bersifat polar hingga semi polar sehingga dalam proses ekstraksi digunakan pelarut semi polar hingga polar.

Belum ada penelitian mengenai aktivitas antioksidan pada eceng padi yang dilakukan di Indonesia, oleh karena itu diperlukan adanya penelitian mengenai kandungan fitokimia pada eceng padi dengan menggunakan jenis pelarut yang berbeda untuk meghasilkan ekstrak eceng padi dengan aktivitas antioksidan tertinggi.

\section{METODE PENELITIAN}

\section{Tempat dan Waktu}

Penelitian ini dilaksanakan di Laboratorium Pengolahan Pangan, Laboratorium Analisis Pangan, dan Laboratorium Biokimia dan Nutrisi, Fakultas Teknologi Pertanian Universitas Udayana. Penelitian ini dilakukan pada bulan Februari - April 2019.

\section{Bahan dan Alat}

Bahan yang digunakan dalam penelitian ini adalah tumbuhan eceng padi yang diperoleh dari areal persawahan di Desa Wanasari, Kecamatan Tabanan, Kabupaten Tabanan, Bali dan bahan-bahan kimia seperti 2,2-diphenyl-1-picryl-hydrazyl (DPPH), reagen Folin-Ciocalteu, etanol, akuades, metanol, aseton, standar asam tanat, reagen Follin Denis, standar asam galat, $\mathrm{Na}_{2} \mathrm{CO}_{3}$, $\mathrm{AlCl}_{3}$, dan standar kuersetin.

Alat-alat yang dipergunakan dalam penelitian ini adalah oven, blender (Minyako), ayakan 60 mesh, spektrofotometer (Genesys 10S UV-Vis), rotary evaporator vakum (IKA RV 10 basic), timbangan analitik (Shimadzu ATY224), kertas Whatman No. 1, vortex, pipet volume, pipet mikro, dan alat-alat gelas.

\section{Rancangan Percobaan}

Rancangan yang digunakan pada penelitian ini adalah Rancangan Acak Lengkap (RAL) yang terdiri dari 4 perlakuan jenis pelarut dan 4 kali ulangan sehingga diperoleh 16 unit percobaan. Perlakuan ekstraksi eceng padi dengan perbedaan pelarut yaitu: P1 (Air), P2 (Etanol 70\%), P3 (Metanol 70\%), P4 (Aseton 
70\%). Data yang diperoleh dianalisis dengan sidik ragam, apabila perlakuan berpengaruh, maka dilanjutkan dengan uji Duncan (Steel dan Torrie, 1993).

\section{Pelaksanaan Penelitian \\ Persiapan Bahan Baku}

Bahan baku berupa eceng padi diperoleh dari areal persawahan yang berada di Desa Wanasari, Kecamatan Tabanan, Kabupaten Tabanan, disortasi, dihilangkan akarnya dan dicuci hingga bersih menggunakan air. Eceng padi kemudian dikeringanginkan selama 5 menit pada suhu $28^{\circ} \mathrm{C}$ dan dirajang $( \pm 0,5 \mathrm{~cm})$ lalu dikeringkan dengan menggunakan oven pada suhu $50^{\circ} \mathrm{C}$ selama 9 jam. Eceng padi kering diblender hingga halus dan diayak dengan menggunakan ayakan 60 mesh sehingga diperoleh bubuk. Prosedur perlakuan pendahuluan berdasarkan Noer et al. (2018) dengan modifikasi. Bubuk yang diperoleh selanjutnya dilakukan proses ekstraksi secara maserasi.

\section{Ekstraksi Bubuk Eceng Padi}

Ekstraksi dilakukan dengan metode maserasi menggunakan pelarut yang berbeda yaitu air, metanol, enatol, dan aseton. Proses maserasi berdasarkan Purwati et al. (2017) dengan modifikasi yang dimulai dengan mencampurkan bubuk eceng padi sebanyak 15 gram dengan pelarut menggunakan perbandingan bahan dengan pelarut sebesar 1:20 (b/v). Setelah dicampurkan dengan pelarut, kemudian diaduk dengan alat pengaduk hingga homogen. Selanjutnya dilakukan maserasi dengan perendaman selama 24 jam dan disaring dengan kertas Whatman No.1 hingga mendapatkan filtrat. Residu pelarut pada filtrat yang diperoleh diuapkan dengan rotary evaporator, sehingga diperoleh ekstrak kasar dari eceng padi. Ekstrak tersebut kemudian dilakukan pengujian sesuai dengan parameter yang diamati.

\section{Variabel yang Diamati}

Variabel yang diamati dalam penelitia ini meliputi rendemen yang dihitung berdasarkan berat ekstrak terhadap bubuk (AOAC, 2005), kadar total fenol menggunakan metode spektrofotometri (Sakanaka et al., 2003), kadar total flavonoid menggunakan metode spektrofotometri (Rohman et al., 2006), kadar total tanin menggunakan metode spektrofotometri (Suhardi, 1997), aktivitas antioksidan ( IC $_{50}$ ) menggunakan metode DPPH (Blois, 1958).

\section{HASIL DAN PEMBAHASAN}

Hasil analisis rendemen, kadar total fenol, kadar total flavonoid, kadar total tanin, dan aktivitas antioksidan berdasarkan $\mathrm{IC}_{50}$ dari ekstrak eceng padi dapat dilihat pada Tabel 1.

\section{Rendemen Ekstrak Eceng Padi}

Hasil sidik ragam menunjukan bahwa jenis pelarut berpengaruh sangat nyata $(\mathrm{P}<$ $0,01)$ terhadap rendemen ekstrak eceng padi. Berdasarkan Tabel 1 dapat dilihat bahwa rendemen terendah terdapat pada perlakuan P3 yaitu $24,98 \%$ dan berbeda tidak nyata dengan P2 yaitu $26,17 \%$. Rendemen tertinggi terdapat pada perlakuan P4 yaitu 44,10\%. Hal tersebut menunjukkan bahwa tingkat kepolaran senyawa yang terkandung pada ekstrak eceng padi mendekati kepolaran aseton yang memiliki konstanta dielektrik sebesar 20,70.

Rifai et al. (2018) yang meneliti tentang pengaruh jenis pelarut terhadap aktivitas antioksidan biji alpukat melaporkan bahwa esktrak aseton biji alpukat menghasilkan rendemen tertinggi dibandingkan dengan ekstrak etanol dan ekstrak metanol. 
Tabel 1. Nilai rata-rata rendemen, kadar total fenol, kadar total flavonoid, kadar total tanin, dan aktivitas antioksidan (IC50) dari ekstrak eceng padi.

\begin{tabular}{lccccc}
\hline Jenis Pelarut & Rendemen $(\%)$ & $\begin{array}{c}\text { Total Fenol } \\
(\mathrm{mg} \mathrm{GAE} / \mathrm{g})\end{array}$ & $\begin{array}{c}\text { Total } \\
\text { Flavonoid } \\
(\mathrm{mg} \text { QE/g) }\end{array}$ & $\begin{array}{c}\text { Total Tanin } \\
(\mathrm{mg} \text { TAE/g) }\end{array}$ & IC 50 (mg/ml) \\
\hline P1 (Air) & $29,09 \pm 0,72^{\mathrm{b}}$ & $2,28 \pm 0,18^{\mathrm{d}}$ & $2,68 \pm 0,15^{\mathrm{d}}$ & $2,16 \pm 0,27^{\mathrm{b}}$ & $1,57 \pm 0,16^{\mathrm{a}}$ \\
P2 (Etanol) & $26,17 \pm 1,33^{\mathrm{c}}$ & $11,12 \pm 0,35^{\mathrm{a}}$ & $8,26 \pm 0,75^{\mathrm{a}}$ & $5,18 \pm 0,52^{\mathrm{a}}$ & $0,49 \pm 0,14^{\mathrm{d}}$ \\
P3(Metanol) & $24,98 \pm 1,88^{\mathrm{c}}$ & $9,61 \pm 0,16^{\mathrm{b}}$ & $6,91 \pm 0,50^{\mathrm{b}}$ & $4,83 \pm 0,38^{\mathrm{a}}$ & $0,96 \pm 0,57^{\mathrm{c}}$ \\
P4 (Aseton) & $44,10 \pm 0,72^{\mathrm{a}}$ & $7,96 \pm 0,14^{\mathrm{c}}$ & $4,34 \pm 0,37^{\mathrm{c}}$ & $2,57 \pm 0,10^{\mathrm{b}}$ & $1,19 \pm 0,51^{\mathrm{b}}$ \\
\hline
\end{tabular}

Keterangan: Huruf yang sama dibelakang nilai rata-rata pada kolom yang sama menunjukkan berbeda tidak nyata $(\mathrm{P}<0,05)$.

Hal serupa juga dilaporkan oleh Lumingkewas et al. (2014) bahwa ekstrak aseton daun cengkeh menghasilkan rendemen tertinggi dibandingkan menggunakan pelarut metanol dan etanol.

\section{Kadar Total Fenol Estrak Eceng Padi}

Hasil sidik ragam menunjukan bahwa jenis pelarut berpengaruh sangat nyata $(\mathrm{P}<$ $0,01)$ terhadap kadar total fenol ekstrak eceng padi. Berdasarkan Tabel 1 dapat dilihat bahwa kadar total fenol terendah terdapat pada perlakuan P1 yaitu 2,28 mg GAE/g. Kadar total fenol tertinggi terdapat pada perlakuan $\mathrm{P} 2$ yaitu 11,12 mg GAE/g.

Hasil penelitian menunjukkan bahwa etanol efektif digunakan untuk mengekstrak eceng padi sehingga menghasilkan kadar total fenol yang tertinggi. Hal serupa juga dilaporkan oleh Chandran et al. (2011) bahwa pelarut etanol menghasilkan kadar total fenol tertinggi pada ekstrak eceng padi dengan metode sokletasi serta fraksinasi. Hal tersebut menunjukkan bahwa kepolaran senyawa fenolik ekstrak eceng padi sesuai dengan etanol yang memiliki konstana dielektrik sebesar 24,30. Penggunaan etanol sebagai pelarut membuat senyawa seperti fenolik dalam tanaman terekstraksi, karena senyawa polar akan melarutkan senyawa yang sifatnya juga polar (Najoan et al., 2016). Menurut penelitian yang dilakukan oleh Larson (1988) komponen fenolik dari tanaman secara umum bersifat polar.

Kadar total fenol ekstrak air lebih rendah dibandingkan dengan total fenol ekstrak yang lain. Pelarut air merupakan senyawa yang paling polar dibandingkan pelarut lainnya, sehingga komponen yang bersifat polar seperti karbohidrat ikut terekstrak dan menyebabkan total fenol per berat sampel menjadi rendah (Septian dan Asnani, 2012).

\section{Kadar Total Flavonoid Esktrak Eceng Padi}

Hasil sidik ragam menunjukan bahwa jenis pelarut berpengaruh sangat nyata $(\mathrm{P}<$ $0,01)$ terhadap kadar total flavonoid ekstrak eceng padi. Berdasarkan Tabel 1 dapat dilihat bahwa kadar total flavonoid terendah terdapat pada perlakuan $\mathrm{P} 1$ yaitu 2,68 mg QE/g. Kadar total flavonoid tertinggi terdapat pada perlakuan P2 yaitu 8,26 mg QE/g. Hal ini menunjukkan bahwa pelarut etanol efektif digunakan untuk mengekstrak eceng padi.

Tingkat kepolaran pelarut etanol menunjukkan kecocokan dengan senyawa flavonoid pada eceng padi sehingga dapat menghasilkan ekstrak dengan kadar flavonoid tertinggi. Etanol memiliki konstanta dielektrik sebesar 24,30 yang menunjukkan bahwa etanol merupakan pelarut polar. Hal ini sesuai dengan penelitian Chandran et al. (2011) 
bahwa pelarut etanol menghasilkan kadar total flavonoid lebih tinggi dibandingkan dengan pelarut air, metanol, dan aseton pada ekstrak daun eceng padi. Harbone (1987) menyatakan bahwa golongan senyawa flavonoid dapat diekstrak dengan menggunakan pelarut etanol dengan konsentrasi $70 \%$.

Hasil penelitian menunjukkan bahwa total flavonoid berbanding lurus dengan total fenol pada ekstrak eceng padi. Menurut Larson (1988), komponen fenolik seperti flavonoid yang dikenal sebagai antioksidan primer dari tanaman bersifat polar. Kadar flavonoid lebih rendah dibandingkan dengan kadar fenolik karena flavonoid merupakan bagian dari fenolik (Rambi et al., 2016). Hal serupa juga dilaporkan oleh Chandran et al. (2011) bahwa pelarut etanol menghasilkan kadar total flavonoid tertinggi pada ekstrak eceng padi. Rendahnya kadar flavonoid pada ekstrak dengan pelarut air diduga akibat banyaknya kandungan senyawa nonfenol seperti karbohidrat dan terpene dalam esktrak air (Do et al., 2014).

\section{Kadar Total Tanin Ekstrak Eceng Padi}

Hasil sidik ragam menunjukan bahwa jenis pelarut berpengaruh sangat nyata $(\mathrm{P}<$ $0,01)$ terhadap kadar total tanin ekstrak eceng padi. Berdasarkan Tabel 1 dapat dilihat bahwa kadar total tanin terendah terdapat pada perlakuan P1 yaitu 2,16 mg TAE/g. Kadar total tanin tertinggi terdapat pada perlakuan P2 yaitu 5,18 $\mathrm{mg}$ QE/g dan berbeda tidak nyata dengan perlakuan P3 yaitu 4,83 mg QE/g. Hal ini menunjukkan bahwa etanol efektif digunakan untuk mengekstrak tanin pada eceng padi.

Menurut Pandey dan Shalini (2014) etanol dapat melarutkan tanin. Tingkat kepolaran etanol sesuai dengan senyawa tanin pada eceng padi sehingga etanol dapat menghasilkan kadar total tanin yang paling tinggi dibandingkan dengan pelarut lainnya. Chandran et al. (2011) melaporkan bahwa

pelarut etanol menghasilkan kadar total tanin tertinggi pada ekstrak eceng padi. Ekstrak tanin tidak dapat murni $100 \%$ karena selain terdiri dari tanin, terdapat pula zat non tanin seperti glukosa dan hidrokoloid yang memiliki berat molekul tinggi (Pizzi, 1983).

\section{Aktivitas Antioksidan (IC50) Ekstrak Eceng Padi}

Hasil sidik ragam menunjukan bahwa jenis pelarut berpengaruh sangat nyata $(\mathrm{P}<$ 0,01) terhadap aktivitas antioksidan berdasarkan nilai IC $_{50}$ ekstrak eceng padi. Berdasarkan Tabel 1 dapat dilihat bahwa nilai $\mathrm{IC}_{50}$ tertinggi dihasilkan pada perlakuan P1 sebesar $1,57 \mathrm{mg} / \mathrm{mL}$. Hal ini menunjukkan bahwa perlakuan dengan menggunakan pearut air menghasilkan aktivitas antioksidan terendah dibandingkan dengan pelarut etanol, metanol, dan aseton, sedangkan nilai $\mathrm{IC}_{50}$ terendah dihasilkan pada perlakuan P2 sebesar $0,49 \mathrm{mg} / \mathrm{mL}$ yang menunjukkan bahwa dengan menggunakan pelarut etanol menghasilkan aktivitas antioksidan tertinggi dibandingkan dengan pelarut air, metanol, dan aseton. Hasil penelitian menunjukkan bahwa pelarut etanol mampu menghasilkan total fenolik, flavonoid, dan tanin yang paling tinggi sehingga hal tersebut juga berpengaruh terhadap aktivitas antioksidan dari ekstrak eceng padi. Ekstraksi eceng padi dengan menggunakan pelarut etanol dapat menghasilkan aktivitas antioksidan tertinggi pada ekstrak eceng padi dibandingkan dengan menggunakan pelarut metanol, aseton, dan air. Aktivitas antioksidan dipengaruhi oleh meningkatnya fenol dan flavonoid pada bahan sehingga semakin tinggi total fenol dan flavonoid maka semakin tinggi juga aktivitas antioksidannya.

Shahidi dan Naczk
mengemukakan bahwa senyawa yang
tergolong antioksidan alami dari golongan
senyawa fenolik seperti senyawa fenolik
sederhana, flavonoid, dan tanin.




\section{KESIMPULAN DAN SARAN}

\section{Kesimpulan}

Berdasarkan hasil dan pembahasan penelitian maka dapat disimpulkan sebagai berikut.

1. Jenis pelarut berpengaruh sangat nyata terhadap aktivitas antioksidan, kadar total fenol, kadar total flavonoid, dan kadar total tanin dari ekstrak eceng padi.

2. Pelarut terbaik yang dapat digunakan untuk mengekstrak eceng padi adalah pelarut etanol yang memiliki aktivitas antioksidan berdasarkan $\mathrm{IC}_{50}$ sebesar $0,49 \mathrm{mg} / \mathrm{mL}$, rendemen sebesar $26,17 \%$, kadar total fenol sebesar $11,12 \mathrm{mg}$ GAE/g, kadar total flavonoid sebesar $8,26 \mathrm{mg} \mathrm{QE} / \mathrm{g}$, kadar total tanin sebesar $5,18 \mathrm{mg} \mathrm{TAE} / \mathrm{g}$.

\section{Saran}

Perlu dilakukan penelitian lebih lanjut mengenai rasio bahan dan pelarut dengan menggunakan etanol sehingga diperoleh rasio yang tepat untuk menghasilkan esktrak eceng padi dengan aktivitas anioksidan tertinggi.

\section{DAFTAR PUSTAKA}

AOAC. 2005. Official Methods of Analysis of The Association of Official Analytical Chemical. Benjamin Franklin Station, Washington.

Blois, M.S.1958. Antioxidants determination by the use of a stable free radical. Journal Nature 181(4617) : 1199 1200.

Chandran, R., P. Thangaraj, S. Shanmugam, S. Thankarajan, dan A. C. Karuppusamy. 2011. Antioksidant and anti-inflammatory potential of Monochoria Vaginalis (Burm. F.) C. Presl. : a wild edible plant. Journal of Food Biochemistry.
Do, Q. D., A. E. Angkawijaya, P. L. TranNguyen, L. H. Huynh, F. E. Soetaredjo, dan S. Ismadji. 2014. Effect of extraction solvent on total phenol content, total flavonoid content, and antioxidant activity of Limnophila aromatica. Journal of Food and Drug Analysis 22(2014) : 296 - 302.

Harborne, J. B. 1996. Metode Fitokimia: Cara Menganalisis Tanaman. Edisi Ke 2. Terjemahan Kosasi Padmawinata. Institut Teknologi Bandung, Bandung.

Kemit, N., I. W. R. Widarta, K. A. Nocianitri. 2016. Pengaruh jenis pelarut terhadap kandungan senywa flavonoid dan aktivitas antioksidan ekstrak daun alpukat (Persea americana Mill). Jurnal ITEPA. 5(2): $130-141$.

Larson, R. K. 1988. On the Double Object Construction. Linguistic Inquiry 19 : 335-391.

Latha, B. dan M. S. Latha. 2013. Antioxidant and curative effect of Monochoria vaginalis methanolic extract against carbon tetrachloride induced acute liver injury in rats. Der Pharma Chemica. $5(1): 306-312$.

Meloan, C. E. 1999. Chemical Separation.New york : J. Willey.

Najoan, J. J., J. R. R. Max, dan S. W. Defny. 2016. Uji fitokimia dan aktivitas antioksidan ekstrak etanol daun tiga (Allophylus cobbe L.). Pharmacon Jurnal Ilmiah Farmasi-Unsrat. 5(1) : 266 $-274$.

Noer, S., D. P. Rosa, dan G. Efri. 2018. Penetapan kadar senyawa fitokimia (tanin, saponin dan flavonoid sebagai kuersetin) pada ekstrak daun inggu (Ruta angustifolia L.). Eksakta: Jurnal Ilmu-ilmu MIPA. 18(1) : 19- 29.

Novita, M., M. I. Sulaiman, dan S. Yura. 2016. Pengaruh jenis pelarut terhadap ativitas antioksidan dan kandungan fenol beberapa jenis bayam dan sayuran 
lain. Jurnal Ilmiah Mahasiswa Pertanian Unsyiah. 1(1) : 935 - 940.

Pandey, A. dan T. Shalini. 2014. Concept of standarization, extraction and pree phytochemical screening strategies for herbal drug. Journal of Pharmacognosy and Phytochemistry. 2(5) : $115-119$.

Pizzi, A. 1983. Tannin-Based Wood Adhesives. In A. Pizzi. Ed. Wood Adhesives Chemistry and Technology. Marcel Dehler, Inc. New York. 178 243.

Purwati, S., V. T. L. Sonja, dan Samsurianto. 2017. Skrining fitokimia daun saliara (Lantana camara L.) sebagai pestisida nabati penekan hama dan insidensi penyakit pada tanaman holtikultura di Kalimantan Timur. Prosiding Seminar Nasional Kimia Unmul. 153 - 158.

Putri, Y. D., A. H. Holis., M. Ida., dan D. A. Anisa. 2014. Pemanfaatan tanaman eceng-ecengan (Ponteridaceae) sebagai agen fioremediasi dalam pengolahan lombah krom. Indonesian Journal of Pharmaceutical Science and Technology. 1(1) : $20-25$.

Rambi, G. A. D., V. S. Kamu, dan M. R. J. Runtuwene. 2016. Uji fitokimia dan antioksidan dari daun yantan (Blumea chinensis DC). Jurnal Mipa Unsrat Online. 5(01) : $32-35$.

Rifai, G., I. W. R. Widarta, dan K. A Nocianitri. 2018. Pengaruh jenis pelarut dan rasio bahan dengan pelarut terhadap kandungan senyawa fenolik dan aktivitas antioksidan ekstrak biji alpukat (Persea americana Mill.). Jurnal ITEPA. 7(2) : $22-32$.

Romadanu., H. R. Siti, dan D. L. Shanti. 2014. Pengujian aktivitas antioksidan ekstrak bunga lotus (Nelumbo nucifera). Fishtech. 3(1):1 - 7 .

Sakanaka, S., Y. Tachibana, Okada, dan Yuki. 2003. Perparation and antioxidant poperties of ekstract of japanese persimo leaf tea (kakinocha-cha). Food chemistry $89: 569-575$.

Septian, A.T., dan A. Asnani. 2012. Kajian sifat fisikokimia ekstrak rumput laut coklat Sargassum duplicatum menggunakan berbagai pelarut dan metode ekstraksi. Agrointek. 6(1) : 22 28.

Shahidi, F dan M. Naczk. 1995. Food Phenolics. Technomic pub.Co. Inc., Lanceser-Basel.

Steel, R. G. D. dan J. H. Torrie. 1993. Prinsip dan prosedur statistika Suatu Pendekatan Biometrik. Penerjemah B. Sumantri. PT. Gramedia Pustaka, Jakarta.

Suhardi. 1997. Analisis senyawa plifenol produk buah-buahan dan sayuran. Vol 3. Lab. Kimia-Biokimia Pengolahan Fakultas Teknologi Pertanian. Universitas Gadjah Mada. Yogyakarta.

Utami. 2009. Potensi daun alpukat (Presea americana Mill) sebagai sumber antioksidan alami. Jurnal Teknik Kimia UPN Jawa Timur. 2(1) : $58-64$.

Widyawati, P.S., T. D. W. Budianta, F. A. Kusuma, dan E.L. Wijaya. 2014. Difference of solvent polarity to phytochemical content and antioxidant activity of Pluchea indica Less leaves extracts. International Journal of Pharmacognosy and Phytochemical Research. 6(4) : $850-855$.

Wijaya, I. K. A. 2018. Kajian Tentang Pemanfaatan Gulma Padi Sawah. Program Studi Agroekoteknologi. Fakultas Pertanian, Universitas Udayana, Denpasar-Bali.

Xu, B. J. dan S. K. C. Chang, 2007, A comparative study on phenolic and antioxidant activity of legumes as affected by extraction solvents. Journal of Food Science. 72(2) : 159 - 166. 